\title{
The Laschamp-Mono lake geomagnetic events and the extinction of Neanderthal: a causal link or a coincidence?
}

\author{
Jean-Pierre Valet ${ }^{\mathrm{a}, *}$, Hélène Valladas ${ }^{\mathrm{b}}$ \\ a Institut de Physique du Globe de Paris, CNRS UMR7154, Sorbonne Paris-Cité, 1, rue Jussieu, 75238 Paris Cedex 05, France \\ ${ }^{\mathrm{b}}$ Laboratoire des Sciences du Climat et de l'Environnement LSCE/IPSL, CEA-CNRS- UVSQ Avenue de la Terrasse, 91190 Gif-sur-Yvette Cedex, France
}

\section{A R T I C L E I N F O}

Article history:

Received 9 April 2010

Received in revised form

15 September 2010

Accepted 23 September 2010

\begin{abstract}
A B S T R A C T
The causes of Neanderthal extinction and the transition with the modern man in Europe and Near East remain largely uncertain. The two main factors currently proposed are the arrival of a modern human competitor and/or the aptitude of the Neanderthals to survive rapidly changing climatic conditions. None of these hypotheses is fully satisfactory because the Neanderthals experienced other large climatic changes and the duration of overlap of the two populations remains largely unknown and even uncertain. No special attention has been given to the geomagnetic excursions of Laschamp and Mono Lake which are synchroneous with the extinction and were the most dramatic events encountered by the Neanderthals over the past 250 thousand years of their existence. During this period the geomagnetic field strength was considerably reduced and the shielding efficiency of the magnetosphere lowered, leaving energetic particles reach latitudes as low as $30^{\circ}$. The enhanced flux of high-energy protons (linked to solar activity) into the atmosphere yielded significant ozone depletion down to latitudes of 40 $-45^{\circ}$. A direct consequence was an increase of the UV-B radiations at the surface which might have reached at least $15-20 \%$ in Europe with significant impacts on health of human populations. We suggest that these conditions, added to some other factors, contributed to the demise of Neanderthal population.
\end{abstract} (c) 2010 Elsevier Ltd. All rights reserved.

\section{Introduction - the current hypotheses for extinction of Neanderthal}

The causes of Neanderthal demise remain debated in the absence of fully convincing scenario. The role of modern humans is currently considered as a key parameter in Neanderthal extinction. After a long existence the disappearance of the Neanderthals more or less coincides with the onset of expansion of modern humans (Stringer, 2002) in western Eurasia (Mellars, 2006) at about 40 cal ka BP. It seems difficult to envisage that the Neanderthals have been exterminated by the modern population since indications of violence have never been found. Neanderthals and modern humans were similar in many aspects, but advances in technology as well as a more complex social organization could have given the modern men some advantages in the competition for survival. Another factor under consideration is that the daily energetic requirements of Neanderthals were higher than for the modern humans for many reasons and particularly their body mass (Verpoorte, 2006; Roebroeks, 2008). Higher energetic

\footnotetext{
* Corresponding author.

E-mail addresses: valet@ipgp.fr (J.-P. Valet), Helene.valladas@lsce.ipsl.fr (H. Valladas).
}

requirements and higher travel costs would have constrained them to shorter foraging distance. Another suggested cause is that a larger variety of diets would have given the modern man selective advantages such as a more efficient reproduction and a lower mortality. Some authors refer to differences in demography between the two populations. Neanderthal would have been genetically weakened after being isolated for at least $250 \mathrm{kyr}$ in Europe. Mixing and progressive dilution of Neanderthal's genes within a much larger population of modern men could be another cause. In this scenario, the Neanderthal gene pool would have been assimilated rather than replaced. According to recent studies the Neanderthal and the reference human genome sequences shared a common ancestor $\sim 706,000$ years ago, and the human and Neanderthal ancestral populations splitted $\sim 370,000$ years ago (Noonan et al., 2006). The DNA analyses (Grings et al., 1997) performed so far indicate that only a few percent of the genomes of present-day people outside Africa are derived from Neanderthals and thus the latter only had a minor role in the genetic ancestry of present-day humans (Green et al., 2010).

More recent views that should not be disconnected from the previous considerations involve the climatic context. The period of Neanderthal extinction is characterized by a rapid succession of 
climatic events, particularly a short warming episode preceding the cooling which accompanies the Heinrich event $\mathrm{H} 4$ (39.3-38.9 cal ky BP) (Roche et al., 2004) and then a longer warm interval (38.5-36.2 cal ky BP). It is not certain that the climatic fluctuations were instrumental in the demise of the Neanderthals since these extreme temperatures were not exceptional compared with the pattern of climatic fluctuations that the Neanderthals had been surviving for at least $250 \mathrm{kyr}$ in Europe (Bar Yosef, 1993; Hublin, 1998; Tzedakis et al., 2007; Roebroeks, 2008).

There are some indications of Mousterian occupations attributed to Neanderthals in South Spain at ca $35 \mathrm{cal}$ ka (d'Errico and Sanchez-Goni, 2003) and several authors plead for a delayed extinction of the population in this region - the most recent "climatic" scenario (Sepulchre et al., 2007) put forward that a large aridification of Central and Southern Iberia would have delayed the Aurignacian progression (linked to the modern man) towards south and thus the competition between the two populations. In this region the earliest unambiguous Aurignacian material has a ${ }^{14} \mathrm{C}$ age of about $36 \mathrm{ka}$ (d'Errico and Sanchez-Goni, 2003; Zilhao and d'Errico, 1999), but there is no skeletal evidence that allows to consider that the Aurignacians really were modern men. In fact it is not firmly established that the Neanderthal and the modern man indeed coexisted as there is no interstratification of Mousterian and Aurignacian layers.

This very brief overview of possible causes for the extinction of Neanderthal demonstrates the importance of establishing the detailed chronology of the events before one can assess whether there is a causal relation between each factor and the extinction.

\section{Ages and timing of Neanderthal demise and Laschamp event}

\subsection{Evolution of Neanderthal demography}

The chronology for the decrease of the Neanderthal population is constrained by the number of dated sites with evidence for
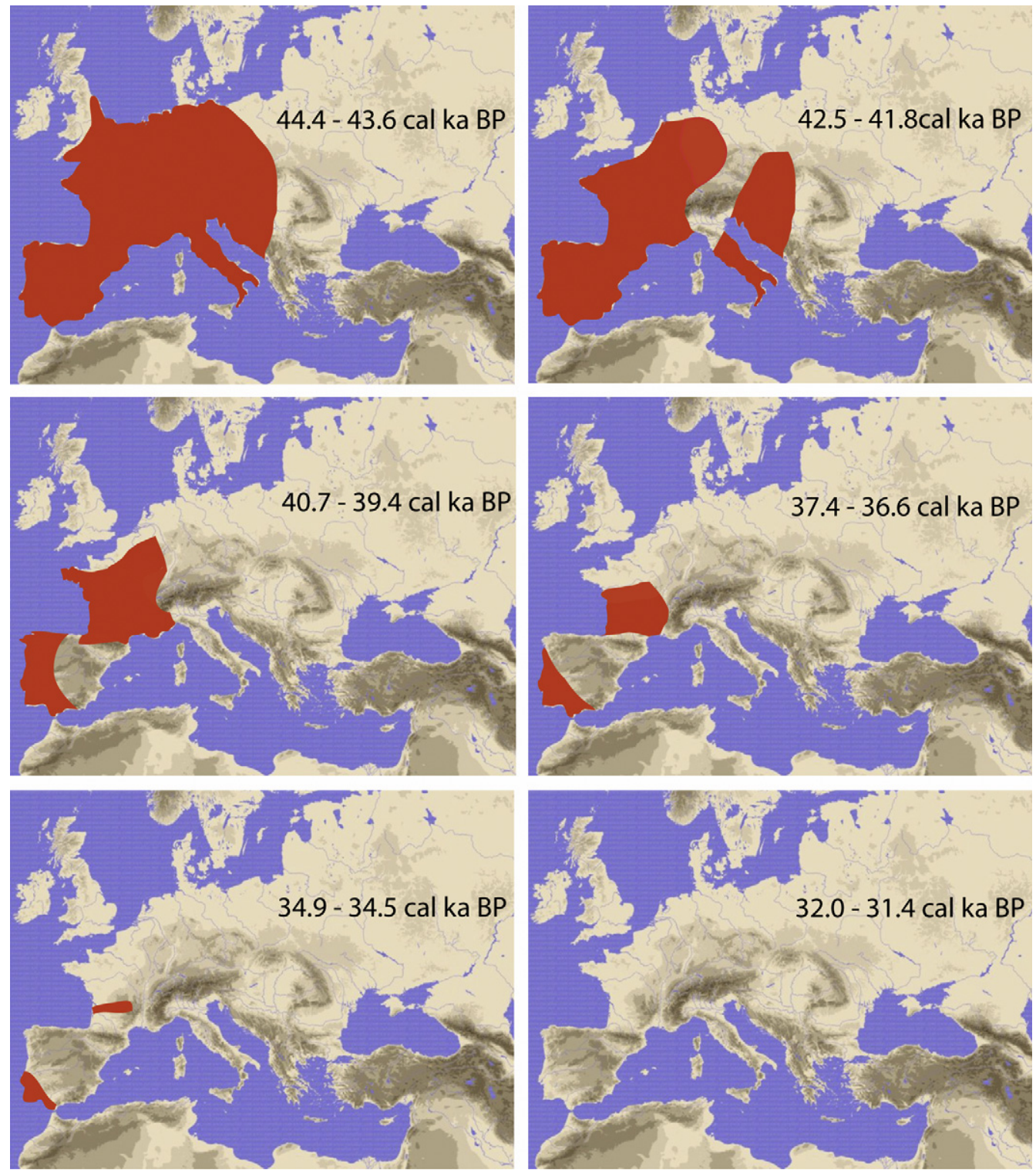

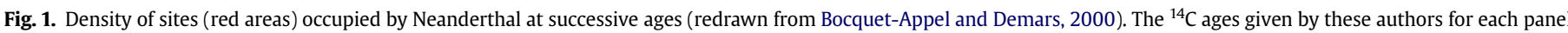

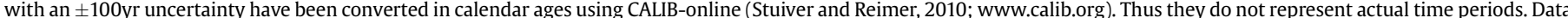

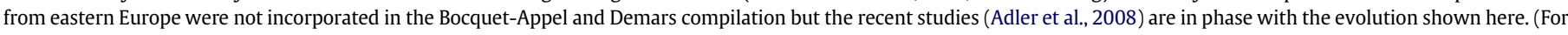
interpretation of the references to color in this figure legend, the reader is referred to the web version of this article). 
occupation or even better with human remains. One of the most complete compilation summarizing the evolution of the population between ca $45 \mathrm{ka}$ and $25 \mathrm{ka}$ has been proposed by Bocquet-Appel and Demars (2000). The ages used in this work rely on uncalibrated radiocarbon dates since the calibration curve accounting for changes in ${ }^{14} \mathrm{C}$ production between 25 and 50 ka has just been published (Reimer et al., 2009). Consequently, the absence of calibrated ages for this period is problematic for establishing the exact chronology of the Neanderthal demise. The geomagnetic field was weakened between 42 and $32 \mathrm{kyr}$ ago. Therefore, the ${ }^{14} \mathrm{C}$ production was high and thus all ${ }^{14} \mathrm{C}$ measurements have minored the ages. Another important factor is the effect of contamination by modern carbon (Mellars, 2006; Blockley et al., 2008) which increases with the age of the samples, e.g., $1 \%$ of modern carbon yields ca $3 \mathrm{kyr}$ (resp. ca $7 \mathrm{kyr}$ ) too young an age at $30 \mathrm{ka}$ (resp. $40 \mathrm{ka}$ ). Although Bocquet-Appel and Demars (2000) attempted to eliminate this problem, they are aware that some results can have been biased towards younger ages. In the present paper, we have taken the new calibration data into account by computing the calendar ages (cal) corresponding to the different periods considered by these authors in their Fig. 2. The results (Fig. 1) indicate that contraction of Neanderthal population began $40 \mathrm{kyr}$ ago and that at 35 cal ka BP the population was restrained to very few sites. Note however that the occupation in southern Iberia relies on very few data and that the period remains controversial in the absence of radiocarbon ages. In any case, it is clear that no site was occupied any more $32 \mathrm{kyr}$ ago. Thus, all indications converge to conclude that the Neanderthal population became practically extinct between 40 and 35 cal ka BP and that Europe was progressively inhabited by the modern man.

\subsection{Stratigraphy and dating of the Laschamp event}

The Laschamp event was discovered from reversed and transitional directions of magnetization (Bonhommet and Zähringer, 1969) that have been recorded during the cooling of volcanic flows at Laschamp, Olby, Louchadière and Royat (Massif central, France). A large number of ages (based on ${ }^{14} \mathrm{C}, \mathrm{K} / \mathrm{Ar}$ and $\mathrm{Ar} / \mathrm{Ar}$ methods) have been published for these flows over the past 40 years. Successive revisions of radioisotopes decay constants and production rate of cosmonuclides progressively increased the age

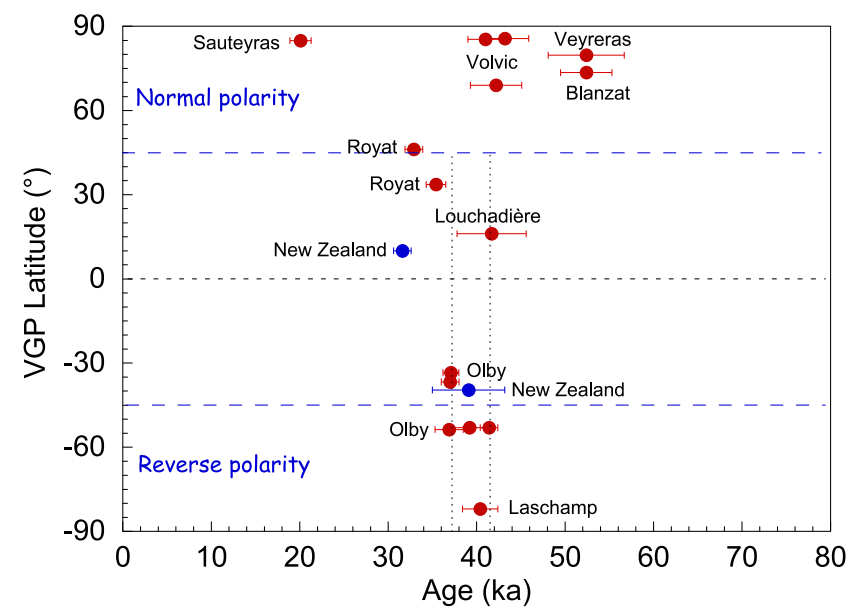

Fig. 2. Summary of the ages recently obtained from lava flows that recorded the Laschamp event as a function of the latitude of their virtual geomagnetic pole (VGP). The VGP latitudes between $90^{\circ} \mathrm{N}$ and $45^{\circ} \mathrm{N}$ correspond to the "normal" polarity of the field. VGPs lower than $45^{\circ}$ define the transition between the two polarities while those between $45^{\circ} \mathrm{S}$ and $90^{\circ} \mathrm{S}$ correspond to reversed polarity. of the event, but the determinations obtained for the past 10 years are consistent with each other. In Fig. 2 are shown the most recent ages obtained for flows distributed between 20 and $40 \mathrm{ka} \mathrm{BP}$ as a function of the latitude of the geomagnetic pole which indicates the occurrence of the Laschamp. The most recently obtained $\mathrm{Ar}-\mathrm{Ar}$ age of the Laschamp flow (Guillou et al., 2004) is $40.4 \pm 1.1 \mathrm{ka}$ (Fig. 2). Two K-Ar ages for Olby at $37.0 \pm 0.65 \mathrm{ka}$ and $39.2 \pm 5 \mathrm{ka}$ (Plenier et al., 2007) are equivalent and in conformity with those of Laschamp (Fig. 2). However the three Royat flows (Fig. 2) indicate a younger mean $\mathrm{K}-\mathrm{Ar}$ age of $34 \pm 0.7 \mathrm{ka}$ (Plenier et al., 2007). Other volcanic records with abnomaleous directions from worldwide localities have been correlated to the Laschamp. The first one was the Skalamaelifell excursion (Levi et al., 1990) from the Reykjanes Peninsula (Iceland). Recently, lavas with excursional directions have been dated at $39.1 \pm 4.1 \mathrm{ka}(\mathrm{Ar}-\mathrm{Ar})$ in the Auckland volcanic field, New Zealand (Cassata et al., 2008). Interestingly, other intermediate directions from the same volcanic area fall at $31.6 \pm 1.8 \mathrm{ka}(\mathrm{Ar}-\mathrm{Ar})$, thus closer to the ages obtained at Royat, which suggests that all these flows (including Royat) would actually be related to the Mono Lake, a slightly younger event which was initially discovered in California (Liddicoat and Coe, 1979).

The most recent $\mathrm{Ar}-\mathrm{Ar}$ age of the Mono Lake is $32.4 \pm 0.3 \mathrm{ka}$ (Singer, 2007), thus not significantly different from the two youngest flows at Royat and Auckland. In fact, the most convincing evidence for the existence of Mono Lake arises from high resolution records of relative paleointensity from marine sediments (Thouveny et al., 2004; Lund et al., 2005; Channell, 2006; Laj et al., 2006) which exhibit two successive dips (Fig. 3a) that are characteristic features of geomagnetic excursions (Guyodo and Valet, 1999) (Fig. 3b). The older pronounced and worldwide intensity low has been dated at $40 \mathrm{ka}$ using $\delta^{18} \mathrm{O}$ isotopic stratigraphy and is
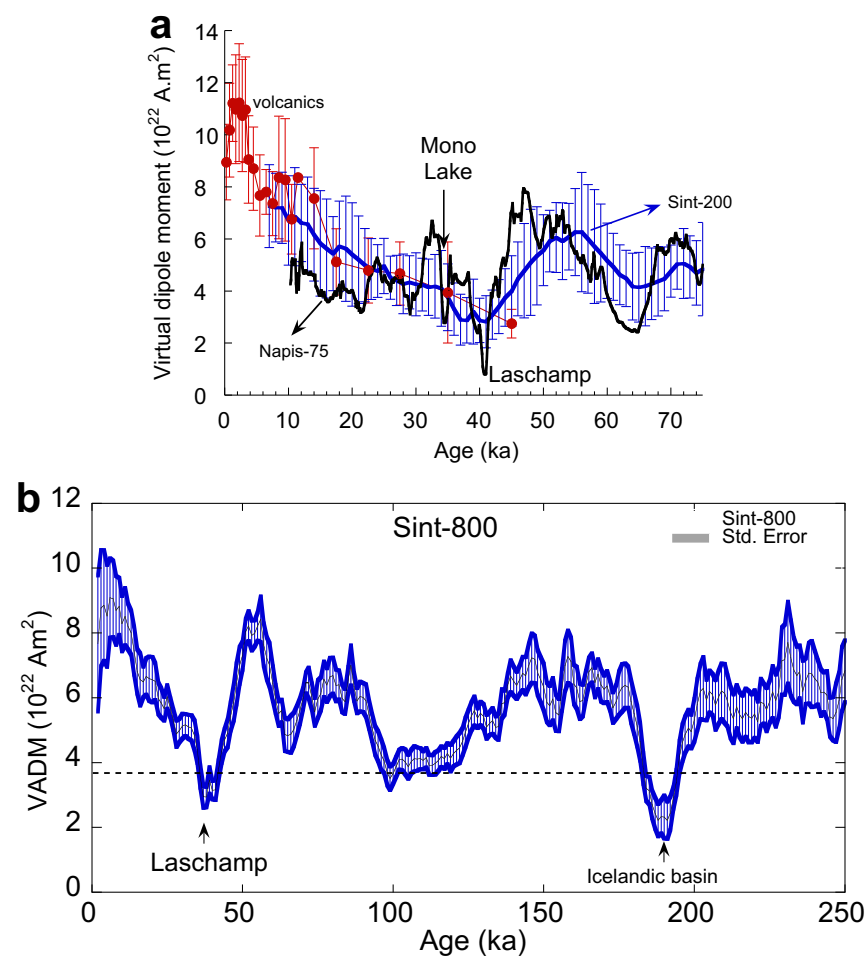

Fig. 3. Composite curves of relative paleointensity derived from a) the Napis compilation of North Atlantic records plotted with the Sint-200 global record calibrated by absolute paleointensities from archaeological and volcanic materials obtained for the past $40 \mathrm{kyr}$ - b) the composite global curve Sint-800 (Guyodo and Valet, 1999; Valet et al., 2005). The differences between the Napis and Sint curves is due to their different resolution (higher for the atlantic records than for Sint-800). 
linked to the Laschamp. The less pronounced second low between 35 and $32 \mathrm{ka}$ is associated with the Mono Lake. Further confirmation of a low field strength during these periods has been given by the enhanced atmospheric ${ }^{10} \mathrm{Be}$ and ${ }^{36} \mathrm{Cl}$ production which has been documented in marine sediments and ice cores and results from an increased penetration of cosmic particles (Carcaillet et al., 2004; Muscheler et al., 2005; Leduc et al., 2006).

Thus, overall the records indicate that the field intensity reached very low values between about 42 and $32 \mathrm{kyr}$ ago and likely did not significantly recover during this period, a process that led to the occurrence of the Laschamp event first and then to the Mono Lake. This long period of reduced intensity reinforces the scenario presented here and goes along with the long decline of the Neanderthal population. It is opposed to the brevity of the $\mathrm{H} 4$ event (39.3-38.9 cal ky BP) which occurred during the Laschamp period.

\section{What did happen during the Laschamp event?}

In the absence of one fully convincing scenario we cannot exclude that several causes have been acting together. Among all possibilities it is worth pointing out that the geomagnetic excursion of Laschamp has been the most "dramatic" event coeval with the period of extinction (Guillou et al., 2004; Plenier et al., 2007). During this time interval the geomagnetic field was considerably weakened and was thus not efficiently shielding the earth from highly energetic particles of cosmic and solar origin. This situation yielded a substantial increase of dangerous UV radiation at the surface. Surprisingly, the impact of this event for human populations has not been investigated so far.

The geomagnetic field can be compared to a field produced by a magnet located along the earth's rotation axis. It is thus mainly dipolar with a north and a south magnetic poles. Several pole positions derived from various volcanic (Fig. 4a) (Plenier et al., 2007) and sedimentary (Channell, 2006; Laj et al., 2006) records (Fig. 4b) of the Laschamp event reach very southern latitudes (beyond $60^{\circ} \mathrm{S}$ ). Thus, the Laschamp must be regarded as a complete field reversal (Valet and Plenier, 2008), more specifically as a period during which the field was reversed for a short time but failed to generate a new stable polarity interval and instead came back to its former polarity. The next question is to know whether the field preserved a dominant dipolar geometry during this period. If this was the case any direction measured at the earth's surface at the same time would point towards the same pole position. Thus during the Laschamp, the reversing pole should follow the same trajectory when viewed from any location on the globe. The pole positions derived from the volcanic records corresponding to the transits from north to south and south to north are scattered in both hemispheres (Fig. 4a) and thus do not fit this prediction (Chauvin et al., 1989; Cassata et al., 2008; Valet and Plenier, 2008; Valet et al., 2008). This dispersion can only be explained if the field was not dipolar as this is the case during reversals. In contrast, many paths (but not all) obtained from sedimentary records (Laj et al., 2006) are more or less similar, which led Leonhardt et al. (2009) to defend that the dipole was weak but still dominant during the reversals. However, this interpretation is not unique and simulations with a dominant non-dipolar field taking into account the time-averaging effect inherent to the signal of the sediments (Valet and Plenier, 2008) are consistent with both the volcanic and sedimentary datasets (Fig. 4b). In any case, we will see below that the exact field geometry is not so critical for the present matter, except for the fact that more local effects are expected with a nondipolar field.

All records agree on the fact that the total field was considerably reduced up to one tenth of its present value (Chauvin et al., 1989), a common feature to all reversals which is actually the most fundamental constraint for the present study. This decrease suggests that the dipole, which represents $80-90 \%$ of the total field measured at the earth's surface, indeed collapsed. Given the rate of variation of the dipole, the duration of this period was not shorter than several hundreds years, if not a few thousand of years. To sum up, the field was reduced over a long time interval which culminated during the directional change marking the Laschamp event itself. The Mono Lake event occurred shortly after and can be seen as an ultimate manifestation of this period of field instability rather than as a real separate event.

The strength and the geometry of the geomagnetic field impose the shape of the magnetosphere surrounding the planet. It is usually regarded as a shield which protects us against penetration of galactic and solar energetic particles but the most efficient protection is due to the atmosphere so that most particles do not reach the surface. Except at the regions surrounding the poles where particles penetrate deeper in the atmosphere the level of radiation (about $2.5 \mathrm{msV} /$ year) remains well below the acceptable dose of $50 \mathrm{msV} /$ year. However the structure of the magnetosphere becomes more complex during periods of low geomagnetic field with a magnetopause being closer to the surface of the planet. Shielding is then less efficient and energetic particles, particularly those emitted during solar eruptions, can
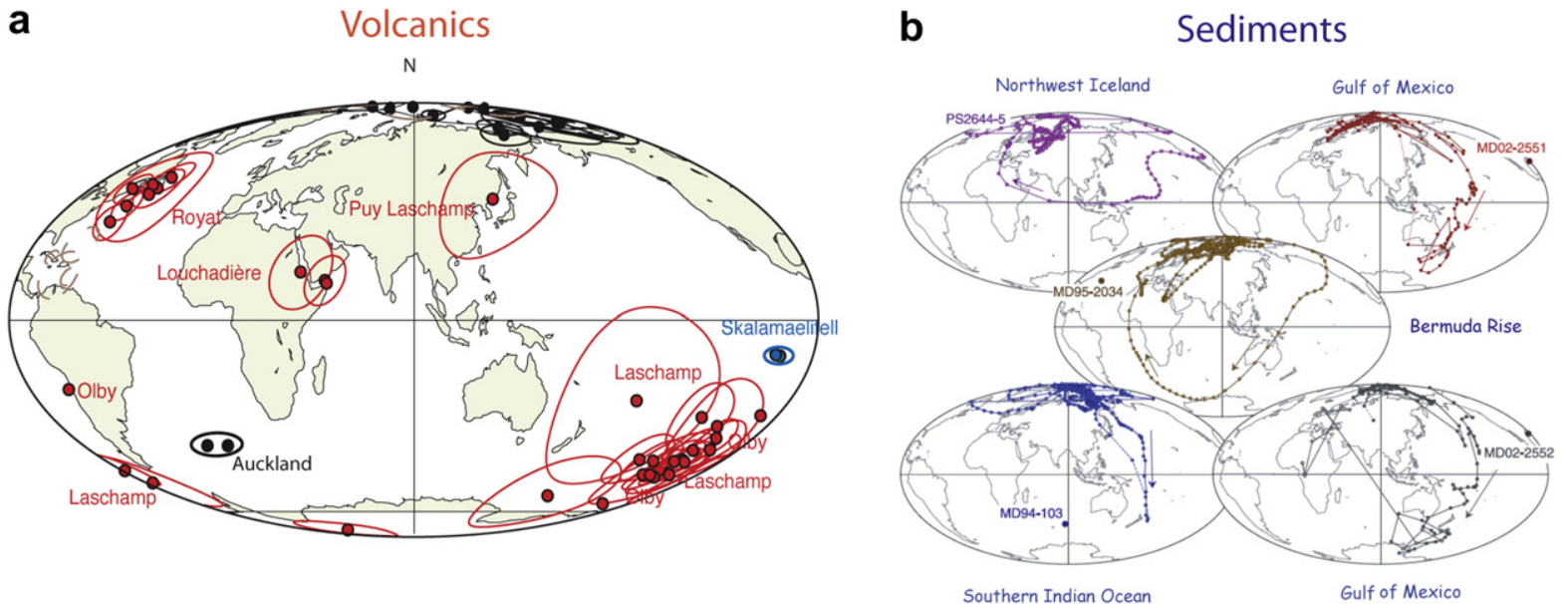

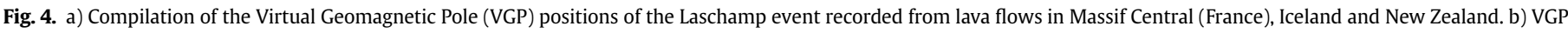
paths recorded from sedimentary sequences in different oceans (redrawn from Laj et al., 2006). 
penetrate into deeper layers of the atmosphere with drastic consequences on the chemical reactions. Precipitating high energetic particles initiates a chain of chemical reactions which transfer the chemically inert species $\mathrm{N}_{2}, \mathrm{H}_{2}$ and $\mathrm{H}_{2} \mathrm{O}$ into nitrogen containing radicals $\mathrm{NO}$ and $\mathrm{NO}_{2}$ and hydrogen containing radicals $\mathrm{OH}$ and $\mathrm{HO}_{2}$ in the middle atmosphere (Randall et al., 2001; Vogt et al., 2007). A direct consequence is the production of nitric oxide (NO) which is a natural ozone depleting chemical. Since most of the ozone layer is located in the mid-stratosphere nitric oxide is more effective for ozone loss than $\mathrm{OH}$ which is found in the upper and lowermost stratosphere. Presently the loss of stratospheric ozone induced by major solar events does not exceed a few percents, but the simulations show that in the magnetosphere of a strongly reduced dipole moment, solar protons of several tens of $\mathrm{MeV}$ access the atmosphere even at midlatitudes (Vogt et al., $2007,2009)$. In the extreme case of a vanishing field leaving the atmosphere entirely exposed to energetic particles, the simulations (Sinnhuber et al., 2003) show that the total ozone loss would reach $40 \%$ in the northern atmosphere after a typical series of three solar events.

The situation becomes more complex with a non-dipolar field geometry (Vogt et al., 2007). With a simple configuration in which dipolar and quadrupolar terms would have the same contribution at the surface, basically the whole atmosphere would become accessible to $256 \mathrm{MeV}$ protons during the reversal. The penetration is much larger at one of the poles depending on the respective signs of the two components, but ozone loss can reach up to $20-40 \%$ at latitudes of $45-50^{\circ}$ (Fig. 5) and persists several years after the solar events (Vogt et al., 2007, 2009). Thus, both the reduced field strength and complex magnetosphere which prevailed during the Laschamp favoured a significant depletion of ozone during many episodes of intense solar activity. Note that a similar distribution of ozone loss is expected (Fig. 5) in the case of a dominant weak dipole. One thus wonders whether this

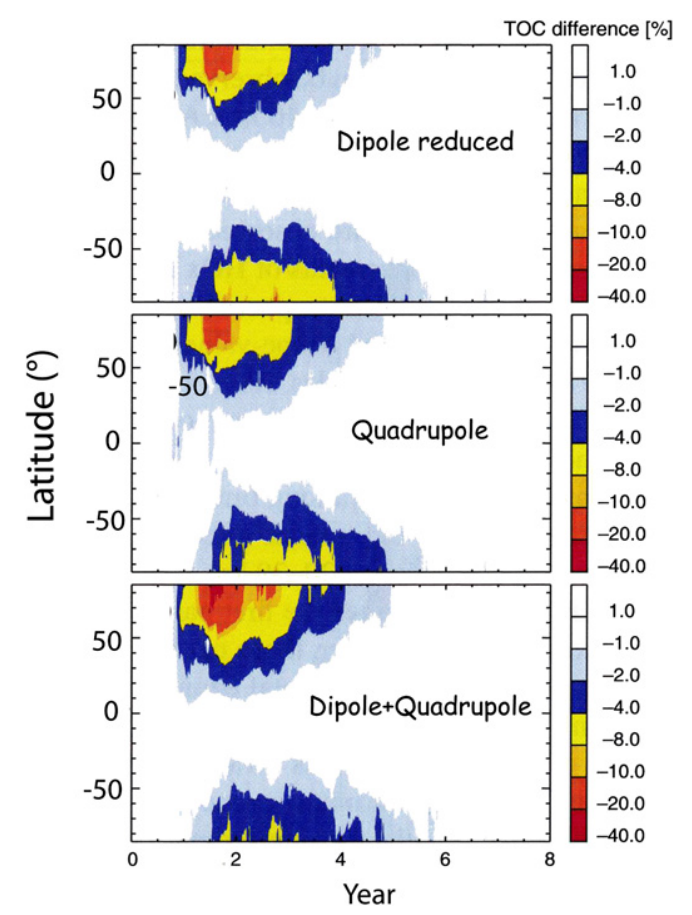

Fig. 5. Simulations of changes of total ozone concentration (TOC) at different latitudes for different mechanisms of reversals as a function of time (redrawn from Vogt et al., 2007). period of very low and complex field had consequences for life at the surface of the planet.

\section{Consequences of ozone depletion on human populations}

The most obvious consequence of large losses of ozone is a significant increase of the UV-B radiation in the wavelength 280-315 nm. During solar protons events the increase is larger at polar latitudes but the surface flux of UV-B increases by more than $20 \%$ at latitudes of $45-50^{\circ}$ (Winkler et al., 2008). The potential health effects of UV radiation due to depletion of stratospheric ozone include skin cancer, tissue damages to eyes and to cellular immunity (de Gruijl et al., 2003). All these effects have been studied for the past 30 years and generated a very large amount of literature (see reviews by de Gruijl et al., 2003 and Norval et al., 2007), most of them being related to the present ozone hole over Antarctica.

Epidemiological studies have shown that basal cell carcinoma, squamous cell carcinoma and cutaneous melanoma are related to UV exposures. A reduction in ozone of $1 \%$ leads to increases of up to $3 \%$ in some forms of non-melanoma skin cancer. It is more difficult to quantify a link between ozone loss and malignant melanoma, which accounts for about $4 \%$ of skin cancer cases, but causes about $79 \%$ of skin cancer deaths. It has been estimated that a $1 \%$ decrease of ozone increases melanoma mortality by $1-2 \%$ (Kripke, 1988). Epidemiological data substantiate a relationship with solar exposure based on experiments which have shown that UV radiations enhance the development of tumors (de Gruijl, 1995). Experimental studies have further demonstrated the important relationship between high exposure at the sun during childhood and a dramatic increase of melanoma skin cancer later in life (de Gruijl, 1995). Although it is not yet possible to produce confident quantitative estimates of the impact of ozone depletion on incidence of melanoma we can consider the impact of the present ozone hole on the most exposed populations. The town of Punta Arenas, Chile, the southernmost city in the world $\left(53^{\circ} \mathrm{S}\right)$, with a population of 154,000, has regularly seen high levels of UV-B radiation each spring for the past 20 years, when the Antarctic ozone hole has moved over the city. An investigation (Abarca and Casiccia, 2002) performed in year 2002 has established that skin cancer cases have increased by 66\% between 1987 and 2000 and that cutaneous malignant melanoma accounting for $19 \%$ of the cases increased by $56 \%$.

Long-term damages to the eyes by UV radiation is difficult to estimate but this aspect is not negligible. Chronic UV exposure frequently cause an outgrowth on the most superficial cell layer of the eyeball and a degeneration of the fibrous layer that covers the lens and thus reduce clarity of vision and even cause blindness (McCarty et al., 1989; Taylor et al., 1989). Cortical cataracts also result from UV radiation (Oriowo and Robinson, 1996; West et al., 2005). Such factors cannot be neglected for a population living from hunting.

It is well known that UV radiation can suppress immune reactions in humans (Ulrich, 2005; Hanneman et al., 2006). Chronic exposure to the increased UV-B that would accompany any persistent ozone loss would also affect the immune system, although recent studies (Brenner and Hearing, 2008) reveal some positive effects on the development of autoimmune diseases. In $10-30 \%$ of the cases the immunity failure would not be transient. The consequences for infectious diseases is not really known but there are indications that the impact could be considerable (Cannell et al., 2006). There is evidence from mouse studies that UV-induced immunodeficiency might be a risk factor for the development of skin tumors (Ulrich, 2002). These problems depend on the characteristics of the population : People who do not tan are 2-3 fold 
more susceptible to immunodeficiency than people who tan readily.

The conditions for generating significant ozone losses between the geographic poles and the midlatitudes were met during the Lachamp and the Mono Lake and likely persisted over a several thousand years long period of reduced geomagnetic intensity surrounding these events. They culminated during the reversal process, so that the ozone layer might have been considerably reduced over at least several centuries and likely several thousand years. Interestingly, the most detailed and complete record of the Laschamp event has been found in France. This testifies that this part of Europe has been very much, if not primarily concerned. We speculate that the long-term persistence of such conditions amplified the incidence of solar ultraviolet radiation with deleterious and cumulative effects on Neanderthal health which ultimately contributed to the collapse of the population.

It is now admitted that Neanderthals had clear skin and a pilosity similar to that of modern man (Patou-Mathis, 2006). Interestingly, a recent paleogenetic study (Lalueza-Fox et al., 2007) from two Neanderthal remains suggests that the population varied in pigmentation levels and that some individuals had reduced pigmentation similar to the pale skin color and red hair of modern humans, thus highly sensitive to UV rays. One may thus wonder why the Laschamp event would have affected the Neanderthal and not the modern man. One possible explanation that comes to mind is that the modern man has survived because of his bigger population distributed over larger and different territories from Africa to eastern Eurasia. It is most likely that these different areas experienced different penetrations of UV-B.

Following another argument (which actually can be invoked as well for the climatic scenario) one may wonder why the Neanderthals survived the previous excursions that occurred during the $250 \mathrm{kyr}$ of their history. The global curve of field intensity (Valet et al., 2005) indicates that the Laschamp-Mono Lake (40-32 ka BP) and the Iceland basin (195 ka BP) events have been the two most dramatic features with very low field intensity. However the amplitude and the latitudinal extent of ozone depletion depend also on field geometry. It is likely that the field was different during the Iceland basin event and consequently the ozone loss may have been less pronounced in western Europe. Moreover the exact distribution of the population at this period is largely unknown.

To conclude, it is reasonable to consider that all conditions were met between 40 and $33 \mathrm{kyr}$ BP for causing major health damages to successive generations of Neanderthal. During this long period the population became increasingly weakened and ultimately disappeared. These exceptional geomagnetic changes may have been associated with other factors, but the synchronism between this low geomagnetic field period and the Neanderthal demise should not be seen as purely accidental.

\section{Acknowledgments}

This paper is dedicated to Georges Valladas and Alexandre Kaczmarczyk. The manuscript benefited helpful suggestions from two anonymous reviewers and from the editor. This is IPGP 3077 contribution number.

\section{Appendix. Supplementary data}

Supplementary data associated with this article can be found in online version at doi:10.1016/j.quascirev.2010.09.010.

\section{References}

Abarca, J., Casiccia, C., 2002. Skin cancer and ultraviolet-B radiation under the Antarctic ozone hole: southern Chile, 1987-2000. Photoderm. Photoimmun. Photomed. 18 (6), 294-302.

Adler, et al., 2008. Dating the demise: Neanderthal extinction and the establishment of modern humans in the southern Caucasus. J. Hum. Evol. 55, 817-833.

Bar Yosef, O., 1993. The Role of Western Asia in Modern Human Origins, the Origin of Modern Humans and the Impact of Chronometric Dating. In: Aitken, M.J., Stringer, C.B., Mellars, P.A. (Eds.). Princeton University Press, Princeton, pp. 132-147.

Blockley, S.P.E., Bronk Ramsey, C., Higham, T.F.G., 2008. The middle to upper paleolithic transition: dating, stratigraphy, and isochroneous markers. J. Hum. Evol. 55 (5), 764-771.

Bocquet-Appel, J.P., Demars, P.Y., 2000. Neanderthal contraction and modern human colonization of Europe. Antiquity 74, 544-552.

Bonhommet, N., Zähringer, J., 1969. Paleomagnetism and potassium argon age determinations of the Laschamp geomagnetic polarity event. Earth Planet. Sci. Lett. 6, 43-46.

Brenner, M., Hearing, V., 2008. The protective role of melanin against UV damage in human skin. Photochem. Photobiol. 84, 539-549.

Cannell, J.J., Vieth, R., Umhau, J.C., Holick, M.F., Grant, W.B., Madronich, S. Garland, C.F., Giovannucci, E., 2006. Epidemic influenza and vitamin D. Epidemiol. Infect., $1-12$

Carcaillet, J.T., Bourlès, D.L., Thouveny, N., Arnold, M., 2004. A high resolution authigenic ${ }^{10} \mathrm{Be} /{ }^{9} \mathrm{Be}$ record of geomagnetic moment variations over the last $300 \mathrm{ka}$ from sedimentary cores of the Portuguese margin. Earht Planet. Sci. Lett. 219, 397-412.

Cassata, W.S., Singer, B., Cassidy, J., 2008. Laschamp and Mono Lake excursions recorded in New Zealand. Earth Planet. Sci. Lett. 268, 76-88.

Channell, J.E.T., 2006. Late Brunhes polarity excursions (Mono Lake, Laschamp, Iceland basin and Pringle falls) recorded at ODP site 919 (Irminger basin). Earth Planet. Sci. Lett. 244, 378-393.

Chauvin, A., Duncan, R.A., Bonhommet, N., Levi, S., 1989. Paleointensity of the Earth's magnetic field and K-Ar dating of the Louchadière volcanic flow (central France): new evidence for the Laschamp excursion. Geophys. Res. Lett. 16 (10) 1189-1192.

d'Errico, F., Sanchez-Goni, M.F., 2003. Neanderthal extinction and the millennial scale climatic variability of OIS3. Quatern. Sci. Rev. 22, 769-788.

de Gruijl, F.R., 1995. Impacts of a projected depletion of the Ozone layer. Consequences Nat. Implic. Environ. Changes 1 (2).

de Gruijl, F.R., Longstreth, J., Norval, M., Cullen, A.P., Slaper, H., Kripke, M.L., Takizawa, Y., van de Leun, J.C., 2003. Health effects from stratospheric ozone depletion and interactions with climate change. Photochem. Photobiol. Sci. 2 $16-28$.

Green, R., et al., 2010. A draft sequence of the Neandertal genome. Science 328, 710-722.

Grings, M., Stone, A., Schmitz, R.W., Krainitzki, H., Stoneking, M., Pääbos, S., 1997. Neanderthal DNA sequences and the origin of modern humans. Cell 90, 19-30.

Guillou, H., Singer, B.S., Laj, C., Kissel, C., Scaillet, S., Jicha, B.R., 2004. On the age of the Laschamp geomagnetic excursion. Earth Planet. Sci. Lett. 227, 331-343.

Guyodo, Y., Valet, J.-P., 1999. Global changes in geomagnetic intensity during the past 800 thousand years. Nature 399, 249-252.

Hanneman, K.K., Cooper, K.D., Baron, E.D., 2006. Ultraviolet immunosuppression: mechanisms and consequences. Dermatol. Clin. 24, 19-25.

Hublin, J.J., 1998. Climatic changes. In: Akazawa, T., Aoki, K., Bar Yosef, O. (Eds.) Paleogeography, and the Evolution of the Neanderthals, in Neanderthals and Modern Humans in Western Asia. Plenum Press, New York and London, pp. 295-310.

Kripke, M.L., 1988. Impact of Ozone depletion on skin cancers. J. Dermatol. Surg. Oncol., 14853-14857.

Laj, C., Kissel, C., Roberts, A.P., 2006. Geomagnetic field behaviour during the Iceland basin and Laschamp geomagnetic excursions: a simple transitional field geometry? Geochem. Geophys. Geosyst. 7 (3). doi:10.1029/2005GC001122.

Lalueza-Fox, C., et al., 2007. A Melanocortin 1 receptor allele suggests varying pigmentation among Neanderthals. Science 318, 1453-1454.

Leduc, G., Thouveny, N., Bourlès, D.L., Blanchet, C.L., Carcaillet, J.T., 2006. Authigenic ${ }^{10} \mathrm{Be} /{ }^{9} \mathrm{Be}$ signature of the Laschamp excursion: a tool for global synchronisation of paleoclimatic archives. Earth Planet. Sci. Lett. 245 (1-2), 19-28.

Leonhardt, R., Fabian, K., Winklhofer, M., Ferk, A., Laj, C., Kissel, C., 2009. Geomagnetic field evolution during the Laschamp excursion. Earth Planet. Sci. Lett. 278 (1-2), 87-95.

Levi, S., Audunsson, H., Duncan, R.A., Kristjansson, L., Gillot, P.Y., Jakobsson, S.P., 1990. Late Pleistocene geomagnetic excursion in Icelandic lavas: confirmation of the Laschamp excursion. Earth Planet. Sci. Lett. 96, 443-457.

Liddicoat, J.C., Coe, R.S., 1979. Mono lake geomagnetic excursion. J. Geophys. Res. 84 261-271.

Lund, S.P., Schwartz, M., Keigwin, L., Johnson, T., 2005. Deep-sea sediment records of the Laschamp geomagnetic field excursion $(41,000$ calendar years before present). J. Geophys. Res. 110. doi:10.1029/2003JB002943.

McCarty, A.C., Fu, C.L., Taylor, H.R., 1989. Epidemiology of pterygium in Victoria, Autralia. Br. J. Ophthalmol. 107, 1481-1484. 
Mellars, P.A., 2006. A new radiocarbon revolution and the dispersal of modern humans in Eurasia. Nature 439, 931-935.

Muscheler, R., Beer, J., Kubik, P.W., Synal, H.A., 2005. Geomagnetic field intensity during the last 60,000 years based on ${ }^{10} \mathrm{Be}$ and ${ }^{36} \mathrm{Cl}$ from the summit cores and ${ }^{14}$ C. Quat. Sci. Rev. 24, 1849-1860.

Noonan, J.P., et al., 2006. Sequencing and analysis of Neanderthal genomic DNA. Science 314, 1113.

Norval, M., Cullen, A.P., de Gruijl, F.R., Longstreth, J., Takizawa, Y., Lucas, R.M., Noonan, F.P., van der Leun, J.C., 2007. The effects on human health from stratospheric ozone depletion and its interactions with climate change, Photochem. Phtobiol. Sci. 6, 232-251.

Oriowo, O.M., Robinson, B.E., 1996. The epidemiology associated with ultraviolet radiation. a current review. Can. J. Optom. 58, 26-33.

Patou-Mathis, M., 2006. Neanderthal, une autre humanité. Perrin, Paris.

Plenier, G., Valet, J.-P., Guérin, G., Lefèvre, J.C., Carter-Stiglitz, B., 2007. Origin and age of the directions recorded during the Laschamp event in the Chaîne des Puys (France). Earth Planet. Sci. Lett. 259, 414-431.

Randall, C.E., Siskind, D.E., Bevilacqua, R.M., 2001. Stratospheric enhancements in the southern hemisphere vortex in winter/spring of 2000. Geophys. Res. Lett. 28, 2385-2388.

Reimer, P.J., et al., 2009. Intcal09 and marine09 radiocarbon age calibration curves $0-50,000$ years cal BP. Radiocarbon 51 (4), 1111-1150.

Roche, et al., 2004. Constraints on the duration and freshwater release of Heinrich event 4 through isotope modelling. Nature 432, 379-382.

Roebroeks, W., 2008. Time for the middle to upper paleolithic transition in Europe. J. Hum. Evol. 55, 1-9.

Sepulchre, P., et al., 2007. H4 abrupt event and late Neanderthal presence in Iberia. Earth Planet. Sci. Lett. 258, 283-292.

Singer, B.S., 2007. Polarity transitions radioisotopic dating. In: Herrero-Bervera, E.H. Gubbins, D. (Eds.), Encyclopedia of Geomagnetism and Paleomagnetism. Springer-Verlag, New-York, pp. 834-839.

Sinnhuber, M., et al., 2003. A model study of the impact of magnetic field structure on atmospheric composition during solar proton events. Geophys. Res. Lett. 30, $1818-1821$.

Stringer, C., 2002. Modern human origins: progress and prospects. Phil. Trans. R. Soc. Lond. B357, 563-579.
Taylor, H.R., West, S.K., Rosenthal, F.S., Munoz, B., Newland, H.S., Emmett, E.A., 1989. Corneal changes associated with chronic UV irradiation. Arch. Ophthalmol. 107, 1481-1484.

Thouveny, N., Carcaillet, E., Moreno, E., Leduc, G., Nérini, D., 2004. Geomagnetic moment variation and paleomagnetic excursions since 400 ka BP: a stacked record of sedimentary sequences of the Portuguese margin. Earth Planet. Sci. Lett. 219, 377-396.

Tzedakis, P.C., Hughen, K.A., Cacho, I., Harvati, K., 2007. Placing Late Neanderthals in a climatic context. Nature 449, 206-208.

Ulrich, S.E., 2002. Photoimmune suppression and photocarcinogenesis. Front. Biosci. 7, 684-703.

Ulrich, S.E., 2005. Mechanisms underlying UV-induced immune suppression. Mutat. Res. 571, 185-205.

Valet, J.-P., Plenier, G., 2008. Simulations of a time-varying non dipole field during geomagnetic reversals and excursions. Phys. Earth. Planet. Inter. 169, 178-193.

Valet, J.-P., Meynadier, L., Guyodo, Y., 2005. Geomagnetic field strength and reversal rate over the past 2 Million years. Nature 435, 802-805.

Valet, J.P., Plenier, G., Herrero-Bervera, E., 2008. Geomagnetic excursions reflect an aborted polarity state. Earth Planet. Sci. Lett. 274, 472-478.

Verpoorte, A., 2006. Neanderthal energetics and spatial behaviour. Before Farming $3,1-6$.

Vogt, J., et al., 2007. Energetic particles in the paleomagnetosphere: reduced dipole configurations and quadrupolar contributions. J. Geophys. Res. 112. doi:10.1029/ 2006JA012224 A06216.

Vogt, J., Sinnhuber, M., Kallenrode, M.B., 2009. Effects of geomagnetic variations on system earth. In: Glassmeier, K.-H., et al. (Eds.), Geomagnetic Field Variations. Springer Verlag, New-York, pp. 159-208.

West, S.K., Longstreth, J.D., Munoz, B.E., Pitcher, H.M., Duncan, D.D., 2005. Model risk of cortical cataract in the US population with exposure to increased ultraviolet radiation due to stratospheric ozone depletion. J. Epidemiol. 162, 1080-1088.

Winkler, H., et al., 2008. Modelling impacts of geomagnetic field variations on middle atmospheric responses to solar proton events on long time scales. J. Geophys. Res. 1, 2302. doi:10.1029/2007JD008574.

Zilhao, J., d'Errico, F., 1999. The chronology and taphonomy of the earliest Aurignacian and its implications for the understanding of Neanderthal extinction. J. World Prehist. 13 (1), 1-68. 